\title{
Dating Violence: A Bibliometric Review of the Literature in Web of Science and Scopus
}

\author{
Nazaret Martínez-Heredia *D, Gracia González-Gijón (D), Andrés Soriano Díaz and Ana Amaro Agudo \\ Department of Pedagogy, University of Granada, 18011 Granada, Spain; graciag@ugr.es (G.G.-G.); \\ asoriano@ugr.es (A.S.D.); anaamaro@ugr.es (A.A.A.) \\ * Correspondence: nazareth@ugr.es
}

\section{check for} updates

Citation: Martínez-Heredia, Nazaret Gracia González-Gijón, Andrés Soriano Díaz, and Ana Amaro Agudo. 2021. Dating Violence: A Bibliometric Review of the Literature in Web of Science and Scopus. Social Sciences 10: 445. https://doi.org/10.3390/socsci 10110445

Academic Editors: Sónia Maria Martins Caridade, Maria Alzira Pimenta Dinis and Nigel Parton

Received: 21 September 2021 Accepted: 18 November 2021 Published: 22 November 2021

Publisher's Note: MDPI stays neutral with regard to jurisdictional claims in published maps and institutional affiliations.

Copyright: (C) 2021 by the authors. Licensee MDPI, Basel, Switzerland. This article is an open access article distributed under the terms and conditions of the Creative Commons Attribution (CC BY) license (https:// creativecommons.org/licenses/by/ $4.0 /)$.

\begin{abstract}
This study has the general purpose of improving the understanding and description of the field of violence in young couple relationships by means of a bibliometric analysis. A descriptive and transversal-retrospective methodology is used, the objective of which is to describe in a quantitative way the information obtained from the production of 842 references registered in the Scopus and Web of Science databases. The results show that during 2017 and 2018, the majority of publications were concentrated, highlighting that the United States is the country with the highest amount of scientific production on violence in intimate relationships. It is important to highlight that more and more countries are investigating this subject, highlighting an increase in production from 2015 onwards. The violence that occurs in the relationships of young couples is a global social and health problem that requires research to be able to deepen its knowledge and in the prevention of this social scourge.
\end{abstract}

Keywords: dating violence; young; bibliometric review; indicators; scientific production

\section{Introduction}

Dating violence is understood as the threat or use of sexual, verbal or physical abuse by one partner against the other (Leen et al. 2013; Rodríguez-Castro and Alonso-Ruido 2015; Rubio-Garay et al. 2017), which means that to properly identify situations of violence, physical and/or sexual aggression must be assessed alongside other forms of violence such as verbal aggression and/or threats, affecting couples who have either been together for a long time or are starting a relationship (Ontiveros et al. 2020).

Violence in young couples' relationships is a very important and fairly widespread public health and social problem. Numerous studies (Ruel et al. 2017; Navarro-Pérez et al. 2020; Dodaj et al. 2020; Taquette et al. 2020; Rodríguez-Domínguez et al. 2020) reveal a high prevalence of this type of violence among young people in different countries. The levels transcend social class, ethnicity, educational level or sexual orientation (Ortiz and Morales 2011). Similarly, in recent years, several systematic reviews have been conducted on the prevalence of violence experienced by young couples (Jennings et al. 2017; Rubio-Garay et al. 2017; Garthe et al. 2017; Yanez-Peñúñuri et al. 2019; Taquette and Monteiro 2019; Bundock et al. 2020), highlighting the existence of health problems such as depression or anxiety, as well as immediate negative effects on well-being and physical, mental and reproductive health, affecting the quality of life and the development of the individual (Sugg 2015; Meza 2018; Duval et al. 2020). Therefore, and according to the WHO (2017), this type of violence is a health problem in different parts of the world, which is why action programmes and policies have been implemented, mainly in the school context, a scenario of socialisation and construction of identity in adolescents (Bundock et al. 2020). But the problem still needs to be addressed in programming for the prevention of violence that often occurs in mixed-sex formats in a critical understanding of the differences and similarities of sex in the perpetration of violence and, finally, the effectiveness of programming efforts aimed at reducing it could be refined and improved (Dardis et al. 2015). 
Several studies (De Puy et al. 2015; Parker et al. 2017; Cho and Huang 2017; Marganski and Melander 2018; Park and Kim 2019; Storer et al. 2019; Tussey and Tyler 2019) argue that more multivariate and longitudinal research is needed, with a lack of gender-specific analytical approaches and focus on contextual factors. In addition, more longitudinal research is needed to cover multiple experiences of violent victimization in various social contexts. There is also a need for a greater critical understanding of gender differences and similarities in the perpetration of domestic violence by young couples, which would help refine and improve knowledge about domestic violence (Dardis et al. 2015; Wincentak et al. 2017; Sianko et al. 2019).

Given this scenario, it is important to determine the research trend, and review the literature related to the concept of "dating violence", taking into account the publications on the Web of Science and Scopus platforms. It is also pertinent to know the management of the programs and consider responding to this social problem that arises and is characterized by the great negative effect that it can have on the health of the person. A bibliometric review of the literature was performed to explore the dating violence with special emphasis on methodological factors and gaps in the literature. Consequently, this bibliometric review aims to analyse existing research on violence in young couples' relationships, helping to understand the needs for its prevention. Bibliometric analysis has been an effective tool to quantitatively analysing academic publications and to assess research trends in different research fields (Wu et al. 2020).

\section{Materials and Methods}

The general objective of this article is to analyse the current existing research in the Web of Science and Scopus databases on violence in young couples' relationships. The following are proposed as specific objectives:

(a) To know the diachronic productivity and the compliance with Price's Law ${ }^{1}$.

(b) To analyse authors and specialized sources by checking the Lotka Law and the Bradford Law.

(c) To analyse the most relevant impact indicators: type of document, country of publication, language, the affiliation of the authors, most-cited journals and references, and authors with the greatest impact. The analysis indicators were established from the review of bibliometric studies (Rodríguez-García et al. 2019; Martínez-Heredia 2020; Rodríguez-García et al. 2020; Pham et al. 2021).

(d) Carry out a bibliometric map of the keywords that deal with the information under study.

This research followed a methodological strategy of bibliometric study, of a descriptive type and of a transversal-retrospective nature, whose objective is to describe in a quantitative way the information obtained (Fuentes and Ortega 2019; Suleiman-Martos et al. 2020). The development of these studies allows us to know the main contributions to the state of the art, as well as to emphasize the need to visualize the results from other research as a starting point to make new scientific contributions (Cabrera-Ramos 2020; Abad Robles et al. 2020). To meet the research objective, firstly a descriptor was defined for the search in the corresponding databases, "dating violence", the most commonly used concept to define violence in young couple relationships, from the Thesaurus ERIC. The choice of this descriptor is mainly focuses on the possibility of bringing together the subject matter of the study, bearing in mind that violence in young couples is the central focus of our research.

Representative and reliable sources are used in the various bibliometric studies carried out in the different areas of research (Fuentes Cabrera et al. 2019; Eckhardt and Massa 2019; Cebrino and Cruz 2020; Badenes-Sastre and Expósito 2021). For this reason, the Web of Science and Scopus databases were taken into consideration. Both databases group together the scientific production with the greatest impact, facilitating access to cited documents, basing their data on the calculation of the $\mathrm{h}$ factor to measure an author's journey (Granda-Orive et al. 2011; Granda-Orive et al. 2013). 
To carry out the descriptive analysis of the quantitative data, the SPSS version 25 programme was used and the analysis and interpretation of co-occurrences of keywords through the VOSviewer programme. The analysis variables (Table 1) were established from the review of previous bibliometric studies in the area of social sciences (Hallinger and Chatpinyakoop 2019; Rodríguez-García et al. 2019; Blanco-Ariza et al. 2019; Amaro Agudo and Martínez-Heredia 2020; Cretu and Morandau 2020): The indicators are:

- Output indicators: diachronic (Price Law) and personal productivity (Lotka's Law).

- Dispersion indicators: correlation between authors and articles.

- Impact indicators: type of document, country of publication, language, the affiliation of authors, journals, references with greater impact, authors with greater production and bibliometric map.

Table 1. Variables and inclusion/exclusion criteria.

\begin{tabular}{ll}
\hline Variable & Inclusion Criteria \\
\hline Year of publication & From the year 2015 to the year 2019 (the year 2020 has been \\
eliminated for not being finalized) \\
Type of document & All is considered \\
Affiliation & All is considered \\
Language & All is considered \\
Publications with greater impact & More than 50 citations \\
Research internationalization & More than 10 publications \\
Authorship of publication & More than 10 publications \\
Reference journals & More than 10 publications \\
Co-occurrence of content & Title, abstract and keywords \\
\hline
\end{tabular}

In the following table, we can see the variables analysed and the criteria are taken into account for their analysis. finalized)

From the year 2015 to the year 2019 (the year 2020 has been eliminated for not being

The statistical variable studied was scientific production following a longitudinal statistical sample between 2015 and March 2020. The data collection took place in July 2020. The data collection took place in July 2020. The final sample of references was 842 ( $\mathrm{n}=842$ ), of which 495 belong to Web of Science and 347 to Scopus. The initial search resulted in 2234 articles, with 35 removed due to duplication. Two reviewers independently screened the articles by abstract and title to determine eligibility for further examination. One thousand one hundred and twenty were retained for further analysis. The reviewers then conducted an in-depth review of the articles resulting in 842 articles meeting inclusion criteria. Refer to Figure 1 for a flowchart of the study selection process. In the following flow diagram, we can see the process followed until obtaining the final sample. 

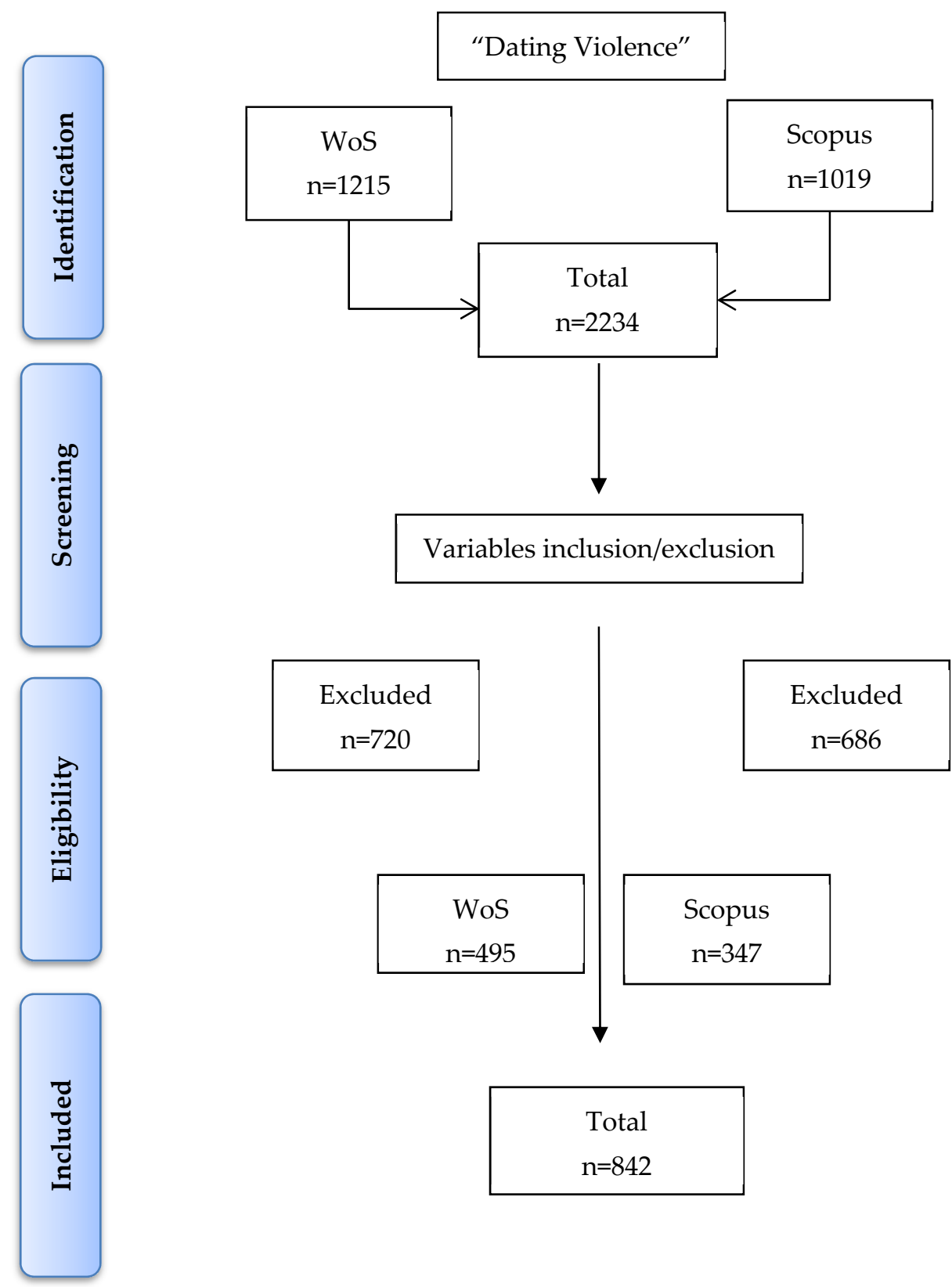

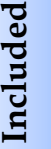

Total

$\mathrm{n}=842$

Figure 1. Flowchart of the review process.

\section{Results}

\subsection{Production Indicators}

- Diachronic productivity

Taking into account the diachronic productivity and using the variable of the year of publication, in both databases, it can be observed that there has been a linear growth in the research topic under study, however, in the In the Web of Science database, it is noted that the highest scientific production occurred during the year 2017 ( $n=103 ; 20.1 \%$ ) and in Scopus in $2018(87 ; \mathrm{n}=25.07 \%)$. The WoS database collects the greatest scientific production during the number of years studied. Figures 2 and 3 show the results analyzed by year and database. 


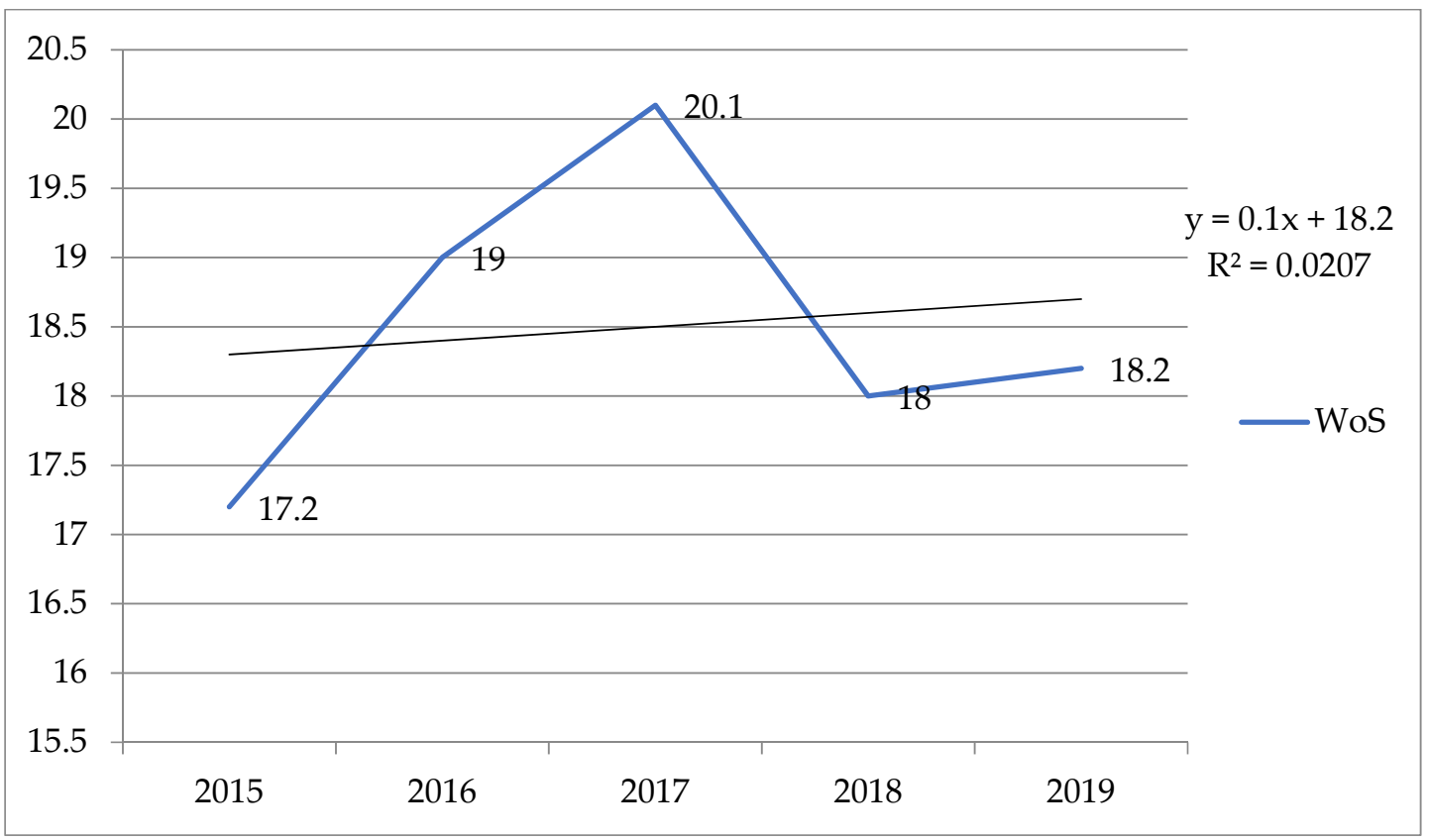

Figure 2. Diachronic production of the scientific production indexed in the Web of Science database.

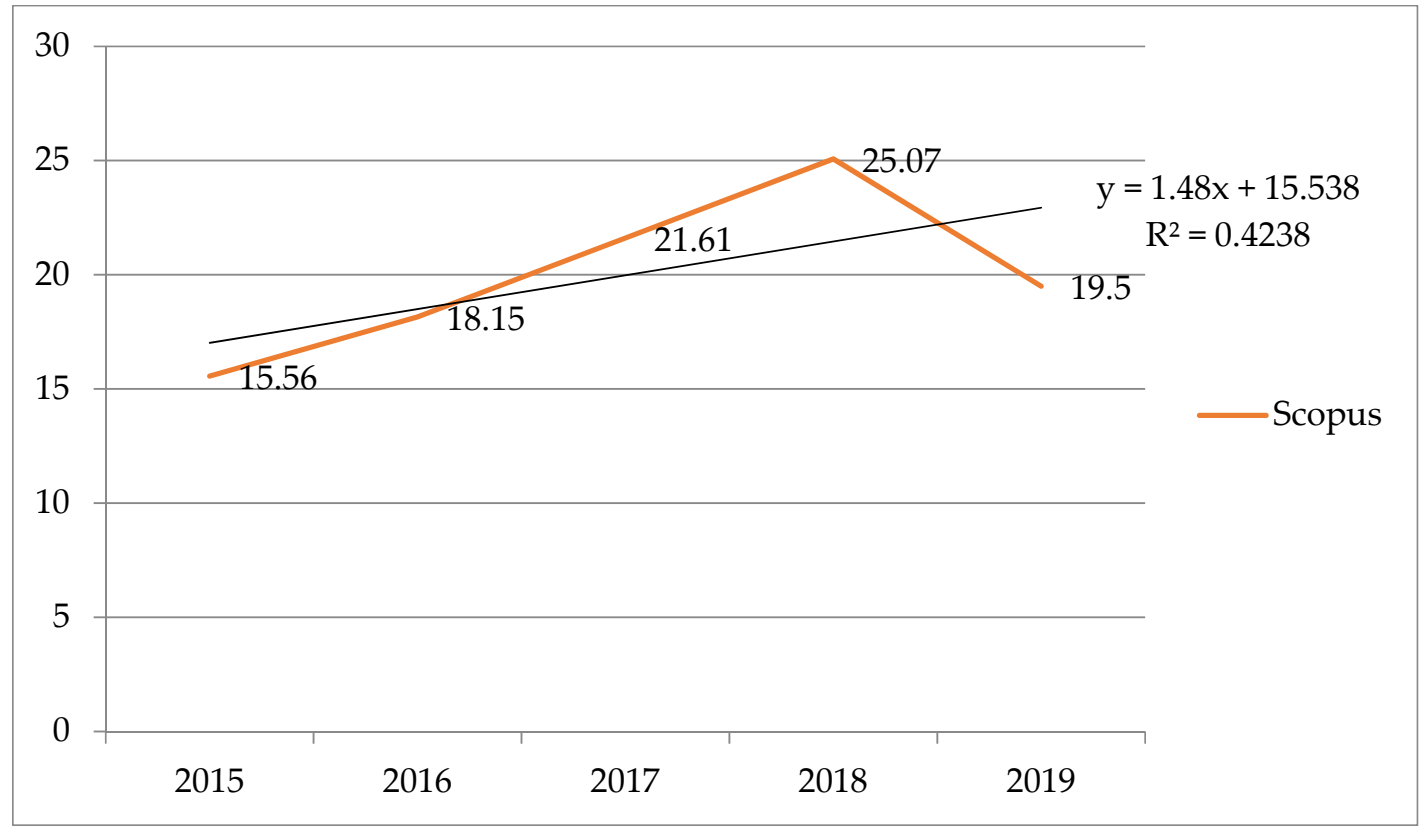

Figure 3. Diachronic production of the scientific production indexed in the Scopus database.

When verifying Price's law of the exponential growth of scientific information, it is fulfilled since there is a phase of linear growth, in which the growth rate remains constant or independent of the size of the system, highlighting that the research is in phase 3-linear growth (Price 1986). The amount of production and its percentage percentages remain very stable, around 85-103 publications and 17\%-20\% in WoS and 54-87 publications and $15 \%-25 \%$ in Scopus.

- Personal productivity

Lotka's law or the law of the productivity of scientific authors indicates that only a small proportion of authors is responsible for the majority of scientific works, so that as the amount of work on a given increases subject, the number of authors decreases 
(Urbizagastegui 2011). In the following graph (Figure 4) it can be seen that the correlation between the number of authors and the number of scientific production in both databases is positive.

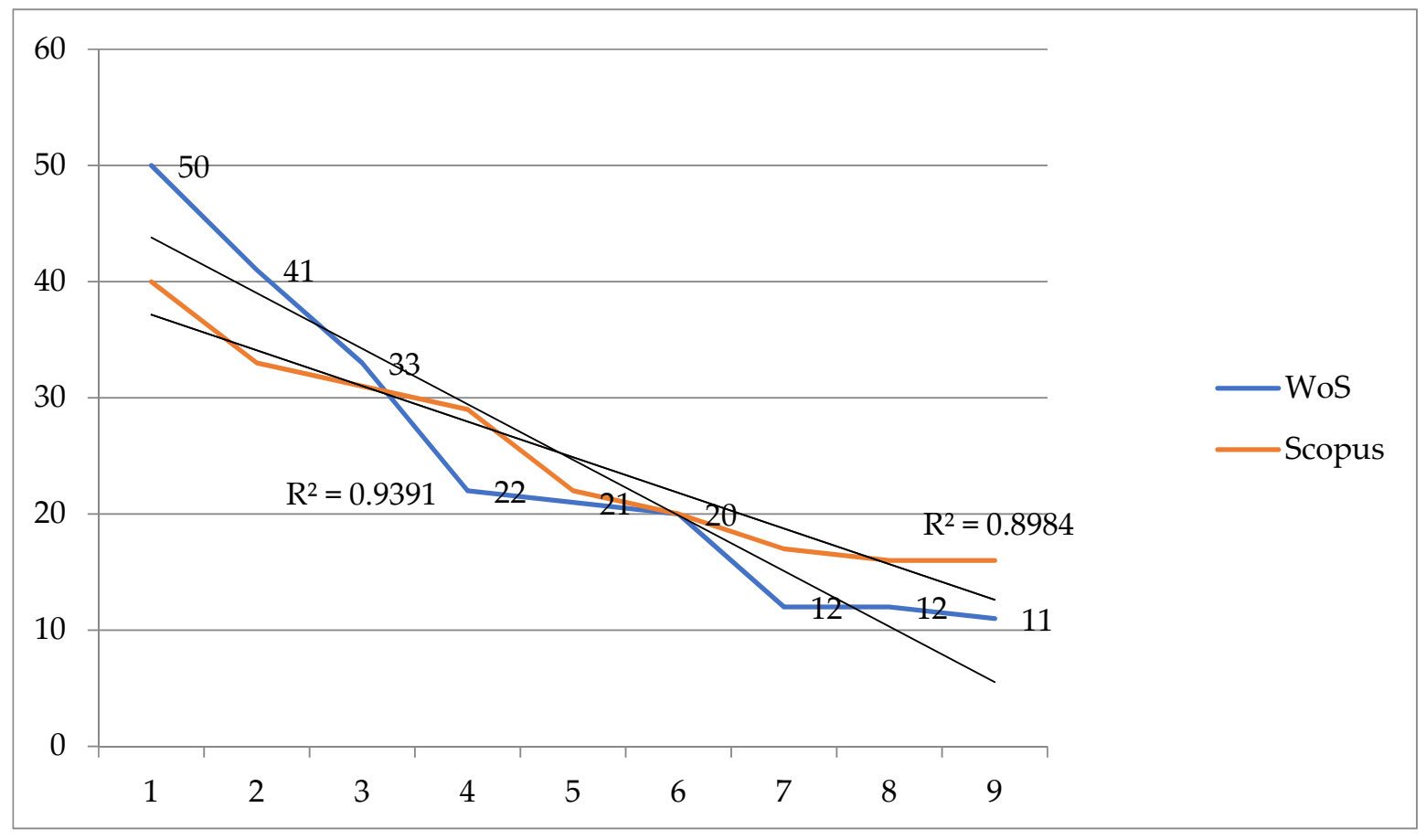

Figure 4. Personal production of the scientific production indexed in the Web of Science and Scopus databases.

The Pearson correlation coefficient in the Web of Science database is $r=-0.948$ and in Scopus $r=-0.969$, so both variables are correlated in the opposite direction, with a linear correlation with a perfect negative slope, assuming an absolute determination between both variables.

\subsection{Indicators of Dispersion}

Bradford's law or dispersion law describes that most articles about a specialized subject could be published by a few specialized journals, together with certain general or dispersal journals, therefore there is a relationship between the published articles and the journals of a given area, stating that a reduced number of journals belong to the nucleus, and this concentrates a similar number of articles than a large number of journals grouped in different areas of greater dispersion (Alvarado 2016). There are a reduced number of journals, which make up the core, which concentrates a similar number of articles as a large number of journals, grouped in areas of greater dispersion (zone 1, 2 and 3). In total we have 17 journals and 342 references distributed in four areas with an average of 86 in each area, so we observe that the nucleus with only 2 journals has 83 references, a number very similar to the other nuclei, which have a greater number of journals (Figure 5).

Both variables are correlated in the opposite direction, with a linear correlation of perfect negative slope between both variables (number of articles and number of journals). The Pearson correlation coefficient in the Web of Science database is $r=-0.747$ and in Scopus $r=-0.991$ (Figure 6). 


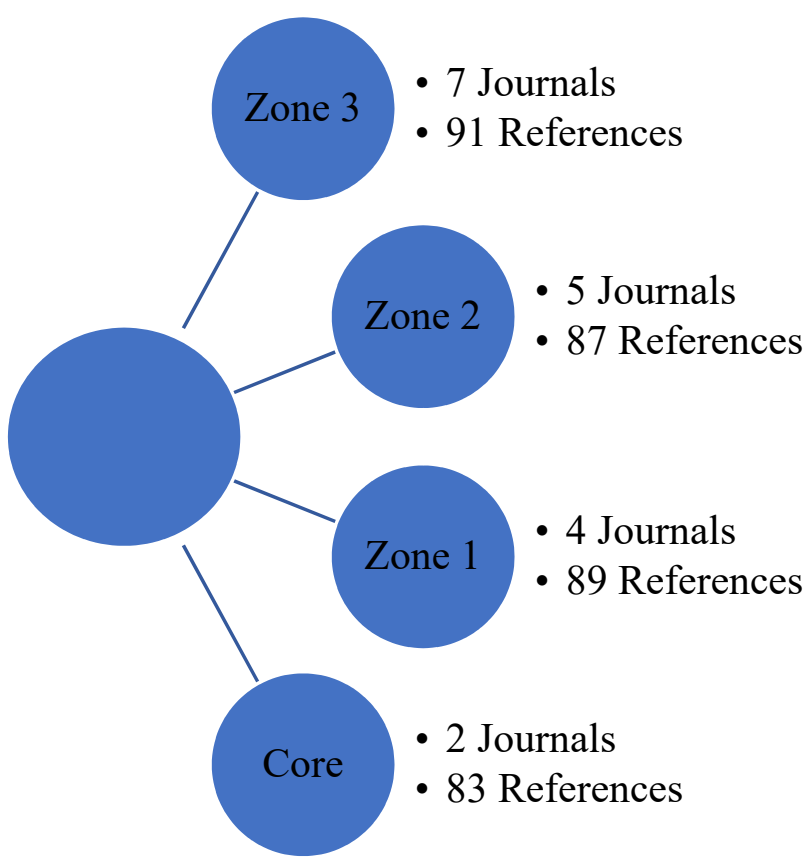

Figure 5. Dispersion of the scientific production indexed in the WoS and Scopus databases.

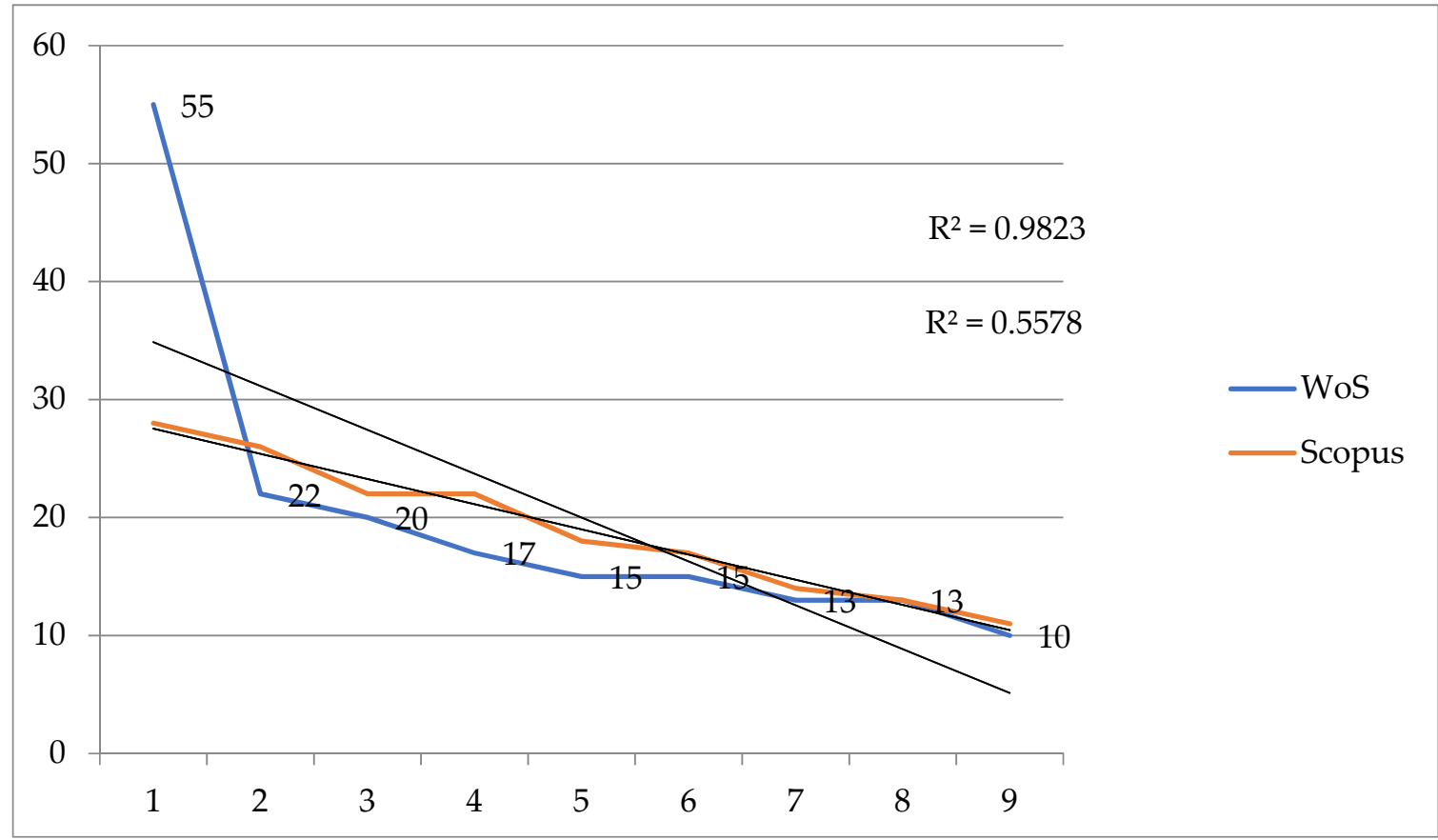

Figure 6. Dispersion of the scientific production indexed in the Web of Science and Scopus databases.

\subsection{Impact Indicators}

\section{- $\quad$ Type of document}

Considering this variable corresponding to the type of document found (Figure 7), it is verified that in both databases the highest percentage of references are scientific articles ( $\mathrm{n}=276 / 79.5 \%$ in Scopus and $\mathrm{n}=92.34 / 92.34 \%$ in WoS). On the other hand, in Scopus we found book chapters with only $7.4 \%(\mathrm{n}=26)$, in addition to reviews $(\mathrm{n}=16 ; 4.6 \%)$ and books $(\mathrm{n}=2 ; 0.57 \%)$. However, in the Web of Science database, we highlight the review $(n=25 ; 5.04 \%)$, the books $(n=7 ; 1.41 \%)$ and conference proceedings $(n=6 ; 1.21 \%)$. 


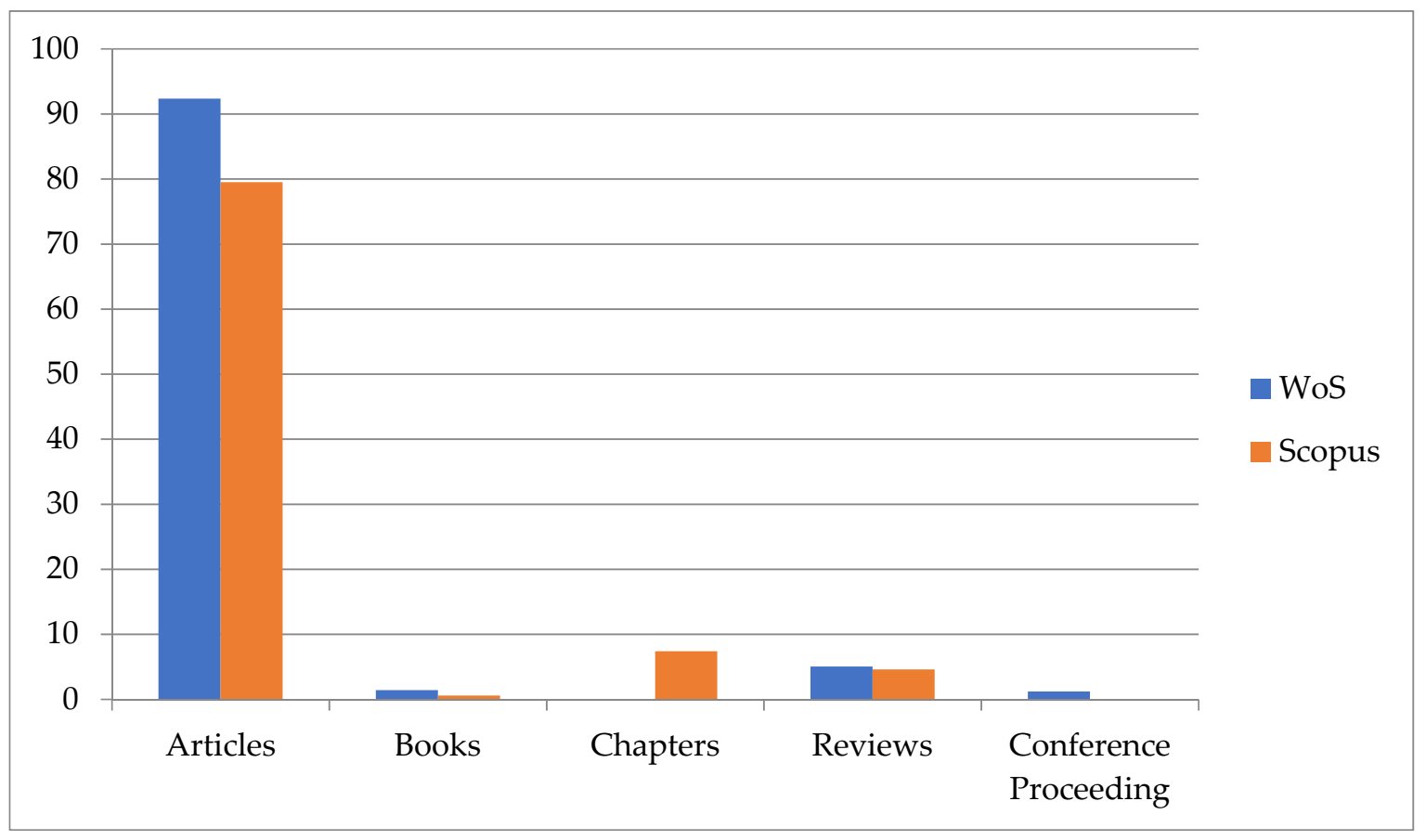

Figure 7. Type of document.

\section{- Affiliation}

The following variable seeks to analyze the institution to which the authors of the documents found are affiliated. Table 2 shows the affiliations of the authors that contain more than 10 publications. The number of references distributed among the 8 institutions with the highest number of affiliations are $5.76 \%, 5.47 \%$ and $4.89 \%$ from the Ohio University, The University of Texas at Arlington and the Centers for Disease Control and Prevention respectively in the Scopus database, the number being higher in the WoS database and coinciding in the Centers for Disease Control and Prevention with a similar percentage $(6.25 \%)$ (Table 3).

Table 2. Number of documents according to affiliation found in the Scopus database.

\begin{tabular}{lcc}
\hline \multicolumn{1}{c}{ Affiliation } & Number & Percentage \\
\hline Ohio University & 20 & 5.76 \\
The University of Texas at Arlington & 19 & 5.47 \\
Centers for Disease Control and Prevention & 17 & 4.89 \\
The University of North Carolina at Chapel Hill & 14 & 4.03 \\
The University of Tennessee, Knoxville & 13 & 3.74 \\
Virginia Commonwealth University & 12 & 3.45 \\
National Center for Injury Prevention and Control & 12 & 3.45 \\
UT Medical Branch at Galveston & 12 & 3.45 \\
\hline
\end{tabular}

\section{- Language}

The language variable (Figure 8) in the scientific production on violence in intimate relationships, the highest percentages are in English in both databases $(n=330 ; 95.1 \%$ Scopus and $n=413 ; 83.26 \%$ Wos), followed by Spanish ( $n=16 ; 4.61 \%$ in Scopus) and Korean in WoS $(\mathrm{n}=44 ; 8.87 \%)$. 
Table 3. Number of documents by affiliation found in the WoS database.

\begin{tabular}{lcc}
\hline \multicolumn{1}{c}{ Authors with the Highest Production } & Number & Percentage \\
\hline United States Department of Health Human Services & 110 & 22.18 \\
National Institutes of Health Nih USA & 87 & 17.54 \\
Nih Eunice Kennedy Shriver National Institute of Child & 42 & 8.47 \\
Health Human Development Nichd & 31 & 6.25 \\
Centers for Disease Control Prevention USA & 25 & 5.04 \\
Intramural CDC HHS & 24 & 4.84 \\
Nih National Institute on Alcohol Abuse Alcoholism Niaaa & 19 & 3.83 \\
NCIPC CDC HHS & 16 & 3.23 \\
NIH National Institute on Drug Abuse Nida & 12 & 2.42 \\
NIH National Institute of Mental Health Nimh & 11 & \\
National Institute of Justice &
\end{tabular}

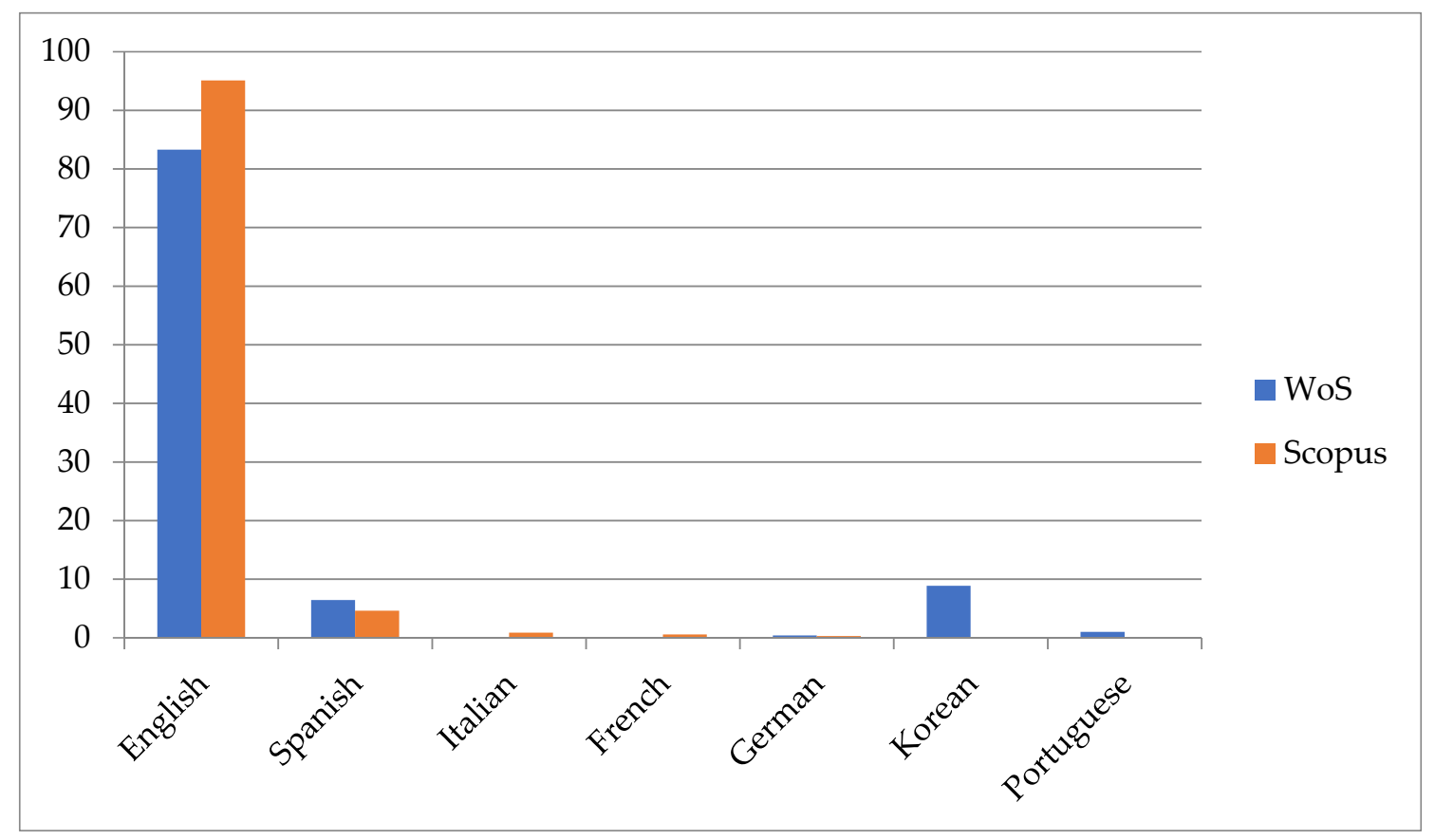

Figure 8. Language of publication.

- $\quad$ Publications with the greatest impact

Regarding the variable publications (Table 4) with the greatest impact, we found that the article "Teen dating violence: A meta-analytic review of prevalence rates", from the journal Psychology of Violence is the most cited with a total of 102 citations. Followed by "Physical dating violence, sexual violence, and unwanted pursuit victimization: A comparison of incidence rates among sexual-minority and heterosexual college students" from the Journal of Interpersonal Violence with 83 citations in the Scopus database. In contrast, we check in the WoS database, the first most cited article "Teen Dating Violence (Physical and Sexual) Among US High School Students Findings From the 2013 National Youth Risk Behavior Survey" has 132 citations and the second coincides with the Scopus database, but in this case with 78 citations. 
Table 4. Most cited references in Scopus.

\begin{tabular}{|c|c|c|c|c|}
\hline Title & Authors & Magazine & Year & Citations \\
\hline $\begin{array}{l}\text { Teen dating violence: A meta-analytic review of } \\
\text { prevalence rates }\end{array}$ & $\begin{array}{l}\text { Wincentak, K., Connolly, J., } \\
\text { Card, N. }\end{array}$ & Psychology of Violence & 2017 & 102 \\
\hline $\begin{array}{l}\text { Physical dating violence, sexual violence, and } \\
\text { unwanted pursuit victimization: A comparison of } \\
\text { incidence rates among sexual-minority and } \\
\text { heterosexual college students }\end{array}$ & $\begin{array}{l}\text { Edwards, KM, Sylaska, } \\
\text { KM, Barry, JE, ( . . ) ), } \\
\text { Walsh, WA, Ward, SK }\end{array}$ & $\begin{array}{c}\text { Journal of } \\
\text { Interpersonal Violence }\end{array}$ & 2015 & 83 \\
\hline $\begin{array}{l}\text { An Examination of the Factors Related to Dating } \\
\text { Violence Perpetration Among Young Men and } \\
\text { Women and Associated Theoretical Explanations: } \\
\text { A Review of the Literature }\end{array}$ & $\begin{array}{c}\text { Dardis, CM, Dixon, KJ, } \\
\text { Edwards, KM, Turchik, JA }\end{array}$ & $\begin{array}{c}\text { Trauma, Violence, and } \\
\text { Abuse }\end{array}$ & 2015 & 78 \\
\hline $\begin{array}{c}\text { Gender Role Attitudes and Male Adolescent } \\
\text { Dating Violence Perpetration: Normative Beliefs } \\
\text { as Moderators }\end{array}$ & $\begin{array}{l}\text { Reyes, HLMN, Foshee, VA, } \\
\text { Niolon, PH, Reidy, DE, } \\
\text { Hall, JE }\end{array}$ & $\begin{array}{l}\text { Journal of Youth and } \\
\text { Adolescence }\end{array}$ & 2016 & 59 \\
\hline $\begin{array}{l}\text { Sexting, psychological distress and dating } \\
\text { violence among adolescents cents and young } \\
\text { adults I [Sexting, psychological disorder and } \\
\text { violent dating in adolescents and young adults }\end{array}$ & $\begin{array}{l}\text { Morelli, M., Bianchi, D., } \\
\text { Baiocco, R., Pezzuti, L., } \\
\quad \text { Chirumbolo, A. }\end{array}$ & Psicothema & 2016 & 56 \\
\hline $\begin{array}{c}\text { The Co-Occurrence of Physical and Cyber Dating } \\
\text { Violence and Bullying Among Teens }\end{array}$ & $\begin{array}{l}\text { Yahner, J., Dank, M., Zweig, } \\
\text { JM, Lachman, P. }\end{array}$ & $\begin{array}{l}\text { Journal of } \\
\text { Interpersonal Violence }\end{array}$ & 2015 & 52 \\
\hline
\end{tabular}

\section{- Internationalization of research}

Regarding the countries with the greatest scientific production of violence in young couples, the United States stands out, with 70.31\% $(\mathrm{n}=244)$ in Scopus and $61.09 \%(\mathrm{n}=303)$ in WoS with a large number regarding to the rest of the countries, as can be seen in Table 5 which represents the countries that have from 10 published documents on the subject. Four were extracted containing a total of 321 of the 347 analyzed for the Scopus database where Spain is in the second position $(n=42 ; 12.10 \%)$ followed by Canada $(n=24 ; 6.91 \%)$ and England with only $3.17 \%(n=11)$, as in the Web of Science database where Spain is the second country $(n=61 ; 12.30 \%)$ followed by Canada $(n=25 ; 5.04 \%)$ and Mexico $(n=17$; $3.43 \%)$.

Table 5. Number of documents according to the country of publication in the Scopus database.

\begin{tabular}{cccccc}
\hline & Scopus & & & WoS & \\
\hline $\begin{array}{c}\text { Country of } \\
\text { Publication }\end{array}$ & Number & Percentage & $\begin{array}{c}\text { Country of } \\
\text { Publication }\end{array}$ & Number & Percentage \\
\hline USA & 244 & 70.31 & USA & 303 & 61.09 \\
Spain & 42 & 12.10 & Spain & 61 & 12.30 \\
Canada & 24 & 6.91 & Canada & 25 & 5.04 \\
England & 11 & 3.17 & Mexico & 17 & 3.43 \\
\hline
\end{tabular}

\section{- $\quad$ Authorship of publication}

Of the total number of authors with the greatest scientific production (Tables 6 and 7 ), those with more than 10 publications on the subject were selected, Shorey, RC (5.76\%) being the one with the most publications, followed by Stuart, GL with 15 publications (4.32\%) and Temple, JR with $3.45 \%$ of the total, in the Scopus database. In contrast, we found a greater number of authors in WoS, although it is highlighted that the aforementioned authors coincide with the Scopus database, highlighting that Temple, JR has a greater number $(0.1 \%)$. 
Table 6. Authors with the highest scientific production in the Scopus database.

\begin{tabular}{lcc}
\hline \multicolumn{1}{c}{ Author Affiliation } & Number & Percentage \\
\hline Shorey, RC & 20 & 5.76 \\
Stuart, GL & 15 & 4.32 \\
Temple, JR & 12 & 3.45 \\
\hline
\end{tabular}

Table 7. Authors with the highest scientific production in the WoS database.

\begin{tabular}{lcc}
\hline \multicolumn{1}{c}{ Affiliation Authors } & Number & Percentage \\
\hline Shorey. RC & 41 & 8.27 \\
Temple, JR & 50 & 10.1 \\
Stuart, GL & 33 & 6.65 \\
Foshee, VA & 12 & 2.42 \\
Reye, s HLM & 12 & 2.42 \\
Ennett, ST & 22 & 4.44 \\
Foshee Vangie, A. & 11 & 2.22 \\
Tharp, AT & 21 & 4.23 \\
Vivolo-Kantor Alana, M. & 20 & 4.03 \\
\hline
\end{tabular}

\section{- $\quad$ Reference journals}

Table 8 shows the matching reference journals in both databases; it can be seen that the journal with the most publications is Journal of interpersonal violence (9.7\% respectively), however, in the Scopus database, the journal Violence and Victims is the journal with the lowest reference (2.6\%) and in the Web of Science database the journal Adolescent Dating Violence Theory Research and Prevention (2.2\%).

Table 8. Journals with the highest production in Scopus and WoS.

\begin{tabular}{lcccc}
\hline \multicolumn{1}{c}{ Publications } & \multicolumn{2}{c}{ Scopus } & \multicolumn{2}{c}{ WoS } \\
\hline Journal of Interpersonal Violence & 28 & 9.7 & 48 & 9.7 \\
Journal of Youth and Adolescence & 26 & 4.4 & 20 & 4 \\
Adolescent Dating Violence Theory & 22 & 4 & 10 & 2.2 \\
Research and Prevention & 22 & 3.2 & 15 & 2.3 \\
Violence Against Women & 18 & 3 & 22 & 4.4 \\
Journal of Adolescent Health & 17 & 3 & 13 & 2.6 \\
Journal of Aggression & 14 & 2.7 & 16 & 3.2 \\
Maltreatment and Trauma & 13 & 2.6 & 13 & 2.6 \\
Psychology of Violence & & & & \\
Violence and Victims & & & & Percentage \\
\hline
\end{tabular}

\section{- Content co-occurrence}

The content co-occurrence analysis applied to the title, abstract and keywords of the analyzed scientific production shows that there are relationships between them. As can be seen in the figure, there are five thematic clusters (green, blue, red, purple and yellow) as we can see in Figure 9. The size of the concepts is proportional to the frequency of appearance and the number of existing connections with other concepts. In the green cluster, the largest concept is "teen", this group is related to descriptors that refer to factors surrounding adolescents. The red group is led by the term "woman" and "dating violence", which allows describing that violence in intimate relationships is directed mainly towards women. On the other hand, the purple cluster is headed by the descriptor "program" and includes descriptors related to its effectiveness and evaluation. The blue cluster encompasses research terms in the field, highlighting the words "literature" and "review". Finally, the yellow cluster highlights "intimate partner violence". This analysis allowed 
us to know that the research on violence in the relationships of young couples focuses on identifying the factors that influence this type of violence.

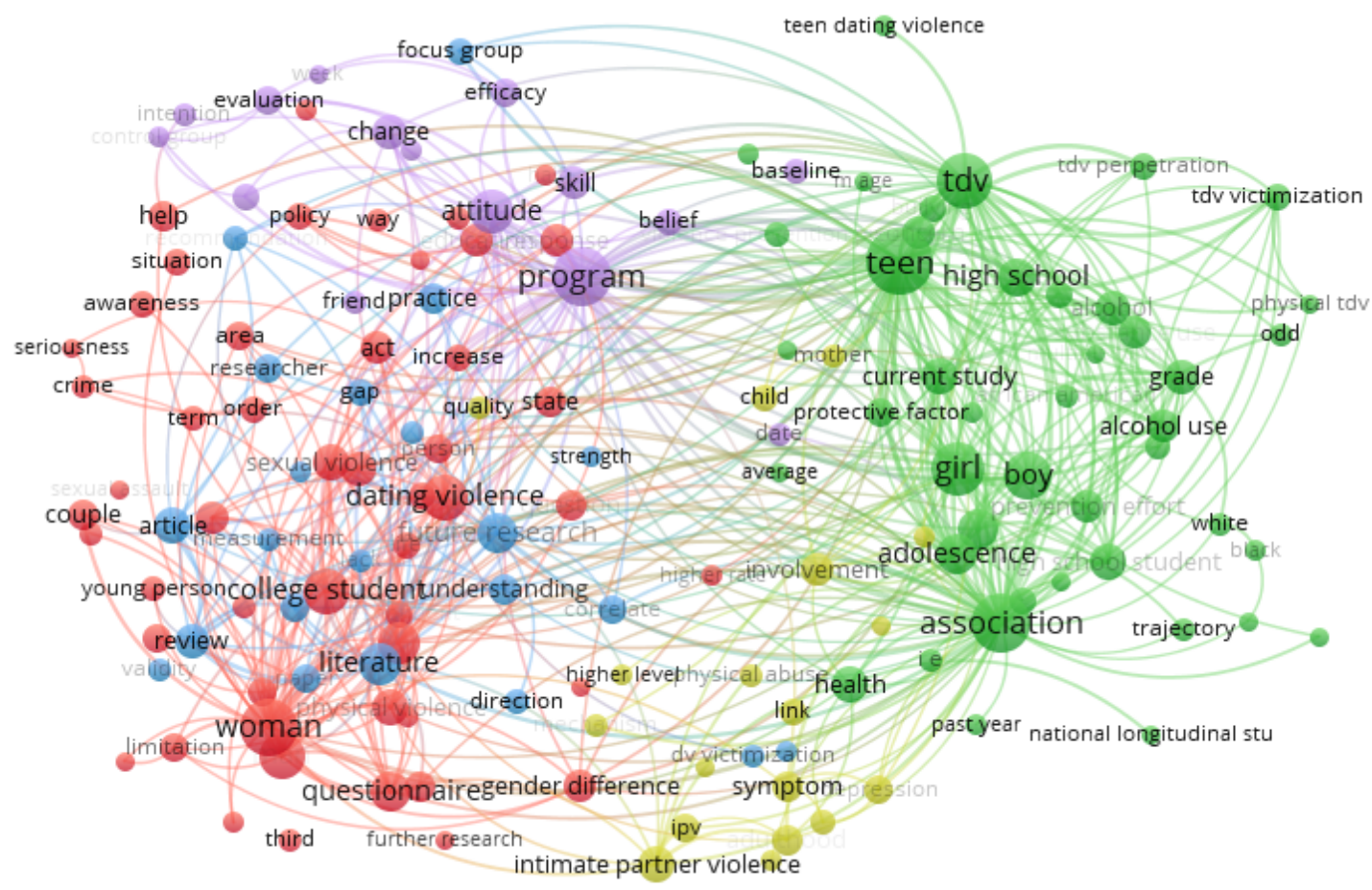

Figure 9. General analysis of co-occurrences.

\section{Discussion}

Traditionally, violence in young couples' relationships has been studied and identified in formal contexts such as marriage and committed or monogamous relationships, but it was only recently that researchers suggested that this type of violence is a significant problem in young, single adults (Duval et al. 2020). The scientific review undertaken consolidates the idea that further work is needed on issues such as violence prevention programming, a critical understanding of gender differences and similarities in violence perpetration that could refine and improve the effectiveness of programming efforts to reduce violence (Dardis et al. 2015). This coincides with the purple cluster, which is headed by the descriptor "program" including descriptors related to its effectiveness and evaluation. Several studies (Dardis et al. 2015; Marganski and Melander 2018; Wincentak et al. 2017; Spencer et al. 2020) conclude that further research is needed on the subject matter for a more critical understanding of gender differences and similarities, and the results show exponential growth in output, which is evidence of an increase since 2015. These studies show that violence in relationships among young people is conceived within the framework of psychological and physical aggression to resolve conflicts that are essential to the relationship itself, increasing the risk of committing subsequent aggressions (Rubio-Garay et al. 2015). Numerous authors such as Rubio-Garay et al. (2017), Garthe et al. (2017), Meza (2018), Zych et al. (2019), Duval et al. (2020) show a greater psychological and sexual victimization in women, as well as the perpetration of psychological aggressions of women towards men and sexual aggressions of men towards women. These results coincide with the red cluster, which is headed by the term "woman", highlighting that violence in intimate relationships is directed mainly towards women.

It is necessary to offer a process of preventive intervention, which allows for a more effective and context-adjusted orientation according to the duration of the relationship, degree of commitment, parental influence, among others (Ravi et al. 2020), as well as prevention programmes focused on the development of optimal emotional regulation and impulse control skills with emphasis on relationships (Ontiveros et al. 2020). 


\section{Conclusions}

This article aims to present a description of the area of research on violence in young couples' relationships, taking into account indicators of production (diachronic and personal productivity), dispersion (correlation between authors and articles) and impact (type of document, country of publication, language, author affiliation, publications, references with greater impact, authors with greater production and bibliometric map) in the Web of Science and Scopus database. Mainly, it is highlighted that the years 2017 (Web of Science) and 2018 (Scopus) led the research of violence in couple relationships, with the United States being the country with the highest amount of scientific production. The correlation between the number of authors and the number of scientific productions in both databases is negative; the authors with the highest number of publications coincide in both databases. The most frequent type of document is scientific articles published in journals with specific themes of violence. There is no doubt that more and more countries are researching this subject, reflecting an increase in production since 2015. Since the violence in young relationships is a global health problem, more research is being done to understand and prevent this type of violence.

This research focused on analyzing the scientific production published during the specified period of time, but several limitations stand out; bibliometric review studies, for which information may be lost due to not using the correct descriptors or due to the lack of feasibility of covering all the databases that currently exist. However, due to the novelty and specificity of the term, it was decided to introduce only the concept "dating violence" as an element of the search engine, the study method does not allow to judge the quality of the analyzed research, and the option of using only the Scopus and WoS database may have limited sample size and diversity.

As a future line of research, it is proposed to systematically analyze the sample in this article, including new descriptors taking into account the main objectives, methodological design, variables under study, analyzed sample and information collection instruments, to give a greater scope to the objectives proposed.

Author Contributions: Conceptualization, N.M.-H., A.S.D., G.G.-G. and A.A.A.; methodology, N.M.H., A.S.D., G.G.-G. and A.A.A.; software, N.M.-H., A.S.D., G.G.-G. and A.A.A.; formal analysis, N.M.-H., A.S.D., G.G.-G. and A.A.A.; writing—original draft preparation, N.M.-H., A.S.D., G.G.-G. and A.A.A.; writing-review and editing, N.M.-H., A.S.D., G.G.-G. and A.A.A.; supervision, N.M.-H., A.S.D., G.G.-G. and A.A.A.; project administration, A.S.D. and G.G.-G.; funding acquisition, A.S.D. and G.G.-G. All authors have read and agreed to the published version of the manuscript.

Funding: FEDER/Junta de Andalucía-Consejería de Transformación Económica, Industria, Conocimiento y Universidades/Proyecto (P18-RT-1475).

Institutional Review Board Statement: Not applicable.

Informed Consent Statement: Not applicable.

Data Availability Statement: The data presented in this study are available on request from the corresponding author.

Conflicts of Interest: The authors declare no conflict of interest.

\section{Note}

1 They are conceptually detailed in the results section.

\section{References}

Abad Robles, Manuel Tomas, Daniel Collado-Mateo, Carlos Fernández-Espínola, Estefania Castillo Viera, and Francisco Javier Gimenez Fuentes-Guerra. 2020. Effects of Teaching Games on Decision Making and Skill Execution: A Systematic Review and Meta-Analysis. International Journal of Environmental Research and Public Health 17: 505. [CrossRef] [PubMed]

Alvarado, Rubén Urbizagástegui. 2016. El crecimiento de la literatura sobre la ley de Bradford. Investigación Bibliotecológica: Archivonomía, Bibliotecología e Información 30: 51-72. [CrossRef] 
Amaro Agudo, Ana, and Nazaret Martínez-Heredia. 2020. Patrimonio como recurso educativo en la ciudad: Revisión teórica y experiencias educativas para el aprendizaje a lo largo de la vida. Cadmo: Giornale italiano di pedagogia sperimentale 1: 9-27. [CrossRef]

Badenes-Sastre, Marta, and Francisca Expósito. 2021. Perception and Detection of Gender Violence, and Identification as Victims: A Bibliometric Study. Annals of Psychology 37: 341-51.

Blanco-Ariza, Ana Beatriz, Alexis Messino-Soza, Ángel Vázquez-García, and Enrique Melamed-Varela. 2019. Social innovation in the non-profit organization framework: A review. Social Sciences 8: 236. [CrossRef]

Bundock, Kerrie, Chan Carmen, and Hewitt Olivia. 2020. Adolescents' help-seeking behavior and intentions following adolescent dating violence: A systematic review. Trauma, Violence, E Abuse 21: 350-66.

Cabrera-Ramos, Juan Francisco. 2020. Producción científica sobre integración de TIC a la Educación Física: Estudio bibliométrico en el periodo 1995-2017. Retos: Nuevas Tendencias en Educación Física, Deporte y Recreación 37: 748-54.

Cebrino, Jesús, and Silvia Portero de la Cruz. 2020. A worldwide bibliometric analysis of published literature on workplace violence in healthcare personnel. PLOS ONE 15: e0242781. [CrossRef]

Cho, Hyunkag, and Luhua Huang. 2017. Aspects of help seeking among collegiate victims of dating violence. Journal of Family Violence 32: 409-17. [CrossRef]

Cretu, Daniela Maria, and Felicia Morandau. 2020. Initial teacher education for inclusive education: A bibliometric analysis of educational research. Sustainability 12: 4923. [CrossRef]

Dardis, Cristina María, Dixon Kristiana, Edwards Katie, and Turchik Jessica. 2015. An examination of the factors related to dating violence perpetration among young men and women and associated theoretical explanations: A review of the literature. Traume, Violence, and Abuse 19: 136-52. [CrossRef] [PubMed]

De Puy, Jacqueline, Sherry Hamby, and Caroline Lindemuth. 2015. Teen dating violence in French-speaking Switzerland: Attitudes and experiences. International Journal of Conflict and Violence (IJCV) 8: 305-15.

Dodaj, Arta, Sesar Kristina, and Šimić Nataša. 2020. Impulsivity and empathy in dating violence among a sample of college females. Behavioral Sciences 10: 117. [CrossRef] [PubMed]

Duval, Alicia, Lanning Beth, and Patterson Megan. 2020. A systematic review of dating violence risk factors among undergraduate college students. Trauma, Violence, \& Abuse 21: 567-85.

Eckhardt, Christopher, and Andrea Massa. 2019. Psychological theories of intimate partner violence. Handbook of Interpersonal Violence across the Lifespan, 1-22. [CrossRef]

Fuentes Cabrera, Arturo, Antonio José Moreno Guerrero, José Santiago Pozo Sánchez, and Antonio-Manuel Rodríguez-García. 2019. Bullying among teens: Are ethnicity and race risk factors for victimization? A bibliometric research. Education Sciences 9: 220. [CrossRef]

Fuentes, Antonio, and José Luis Gallego Ortega. 2019. Análisis bibliométrico sobre educación especial. Profesorado, Revista de Currículum y Formación del Profesorado 23: 307-27.

Garthe, Rachel, Sullivan Terri, and McDaniel Michael. 2017. A meta-analytic review of peer risk factors and adolescent dating violence. Psychology of Violence 7: 45. [CrossRef]

Granda-Orive, José Ignacio de, Adolfo Alonso-Arroyo, and Francisco Roig-Vázquez. 2011. ¿Qué base de datos debemos emplear para nuestros análisis bibliográficos?: Web of Science versus Scopus. Archivos de Bronconeumología 47: 213. [CrossRef] [PubMed]

Granda-Orive, José Ignacio, Adolfo Alonso-Arroyo, Francisco García-Río, Segismundo Solano-Reina, Carlos Andrés Jiménez-Ruiz, and Rafael Aleixandre-Benavent. 2013. Ciertas ventajas de Scopus sobre Web of Science en un análisis bibliométrico sobre tabaquismo. Revista Española de Documentación Científica 36: 011. [CrossRef]

Hallinger, Philip, and Chatchai Chatpinyakoop. 2019. A bibliometric review of research on higher education for sustainable development, 1998-2018. Sustainability 11: 2401. [CrossRef]

Jennings, Wesley G., Chidike Okeem, Alex R. Piquero, Christine S. Sellers, Delphine Theobald, and David P. Farrington. 2017. Dating and intimate partner violence among young person's ages 15-30: Evidence from a systematic review. Aggression and Violent Behavior 3: 107-25. [CrossRef]

Leen, Eline, Emma Sorbring, Matt Mawer, Emma Holdsworth, Bo Helsing, and Erica Bowen. 2013. Prevalence, dynamic risk factors and the efficacy of primary interventions for adolescent dating violence: An international review. Aggression and Violent Behavior 18: 159-74. [CrossRef]

Marganski, Alison, and Lisa Melander. 2018. Intimate partner violence victimization in the cyber and real woeld: Examining the extet of Cyber aggression experiences and its association with in-person dating violence. Journal of Interpersonal Violence 33: 1071-95. [CrossRef] [PubMed]

Martínez-Heredia, Nazaret. 2020. Análisis cienciométrico de mayor impacto acerca del duelo y la pérdida en personas con discapacidad intelectual. Siglo Cero 51: 47-60. [CrossRef]

Meza, Jesús Armando. 2018. Violencia en las relaciones de noviazgo: Una revisión de estudios cualitativos. Apuntes de Psicología 35: 179-86.

Navarro-Pérez, José J., Amparo Oliver, Ángela Carbonell, and Barry H. Schneider. 2020. Effectiveness of a mobile App intervention to prevent dating violence in residential child care. La eficacia de una intervención con aplicación móvil sobre actitudes asociadas a la violencia de pareja en los adolescentes de centros de acogida. Psychosocial Intervention 29: 35-52. [CrossRef] 
Ontiveros, Gabriela, Arthur Cantos, Po-Yi Chen, Ruby Charak, and K. Daniel O'Leary. 2020. Is all dating violence equal? Gender and severity differences in predictors of perpetration. Behavioral Sciences 10: 118. [CrossRef]

Ortiz, Mabel T. López, and Denisse Ayala Morales. 2011. Intimidad y las múltiples manifestaciones de la violencia doméstica entre mujeres lesbianas. Salud y Sociedad 2: 151-74. [CrossRef]

Park, Sihyun, and Sin-Hyang Kim. 2019. Who are the victims and who are the perpetrators in dating violence? Sharing the role of victim and perpetrator. Trauma, Violence, \& Abuse 20: 732-41.

Parker, Elizabeth M., Sarah Lindstrom Johnson, Katrina J. Debnam, Adam J. Milam, and Catherine P. Bradshaw. 2017. Teen Dating Violence Victimization Among High School Students: A Multilevel Analysis of School-Level Risk Factors. Journal of School Health 87: 696-704. [CrossRef] [PubMed]

Pham, Hiep-Hung, Thi-Kieu Dong, Quan-Hoang Vuong, Dinh-Hai Luong, Tien-Trung Nguyen, Viet-Hung Dinh, and Manh-Tung Ho. 2021. A bibliometric review of research on international student mobilities in Asia with Scopus dataset between 1984 and 2019. Scientometrics 126: 5201-24. [CrossRef]

Price, Derek. 1986. Little Science, Big Science ... and Beyond. New York: Columbia University Press, pp. 336-36.

Ravi, Kristen E., Beverly M. Black, Diane B. Mitschke, and Katelyn Pearson. 2020. Karen refugee youths' satisfaction with a teen dating violence prevention program. Journal of Ethnic E Cultural Diversity in Social Work 29: 221-37.

Rodríguez-Castro, Yolanda, and Patricia Alonso-Ruido. 2015. Análisis de los discursos de los y las jóvenes sobre la violencia en las relaciones de pareja. Revista de Estudios e Investigación en Psicología y Educación 1: 15-18. [CrossRef]

Rodríguez-Domínguez, Carmen, Pedro J. Pérez-Moreno, and Mercedes Durán. 2020. Cyber dating violence: A Review of Its Research Methodology. Anales De Psicología/Annals of Psychology 36: 200-9.

Rodríguez-García, Antonio Manuel, Juan Manuel Trujillo, and José Sánchez. 2019. Impact of scientific productivity on digital competence of future teachers: Bibliometric approach on Scopus and Web of Science. Revista Complutense de Educación 30: 623-46. [CrossRef]

Rodríguez-García, Antonio-Manuel, Antonio-José Moreno-Guerrero, and Jesús Lopez Belmonte. 2020. Nomophobia: An individual's growing fear of being without a smartphone-A systematic literature review. International Journal of Environmental Research and Public Health 17: 580. [CrossRef] [PubMed]

Rubio-Garay, Fernando, M. Ángeles López-González, Miguel Ángel Carrasco, and Pedro Javier Amor. 2017. Prevalencia de la violencia en el noviazgo: Una revisión sistemática. Papeles del Psicólogo 38: 135-47. [CrossRef]

Rubio-Garay, Fernando, Miguel Ángel Carrasco, Pedro Javier Amor, and María Angeles López-González. 2015. Factores asociados a la violencia en el noviazgo entre adolescentes: Una revisión crítica. Anuario de Psicología Jurídica 25: 47-56. [CrossRef]

Ruel, Catherine, Francine Lavoie, Martine Hébert, and Martin Blais. 2017. Gender's role in exposure to interparental violence, acceptance of violence, self-efficacy, and physical teen dating violence among Quebec adolescents. Journal of Interpersonal Violence 35: 3079-101. [CrossRef]

Sianko, Natallia, Merita H. Meçe, and Linda Abazi-Morina. 2019. Family functioning among rural teens and caregivers: Interactive influence on teen dating violence. Family Process 59: 1175-90. [CrossRef] [PubMed]

Spencer, Chelsea M., Kristin M. Anders, Michelle L. Toews, and Sarah K. Emanuels. 2020. Risk markers for physical teen dating violence victimization in the United States: A meta-analysis. Journal of Youth and Adolescence 49: 575-89. [CrossRef]

Storer, Heather L., Allison Talan, Alison Swiatlo, Kendra LeSar, Marsha Broussard, Carl Kendall, David W. Seal, and Aubrey Spriggs Madkour. 2019. Context matters: Factors that influence African American teens' perceptions and definitions of dating violence. Psychology of Violence 10: 79. [CrossRef]

Sugg, Nancy. 2015. Intimate Partner Violence: Prevalence, health consequences and intervention. Medical Clinics for North America 99: 629-49. [CrossRef] [PubMed]

Suleiman-Martos, Nora, Luis Albendín-García, José L. Gómez-Urquiza, Keyla Vargas-Román, Lucia Ramirez-Baena, Elena OrtegaCampos, De La Fuente-Solana, and I. Emilia. 2020. Prevalence and Predictors of Burnout in Midwives: A Systematic Review and Meta-Analysis. International Journal of Environmental Research and Public Health 17: 641. [CrossRef]

Taquette, Stella R., Claudia Leite Moraes, Luciana Borges, and Simoni Furtado. 2020. Teen-dating violence: Conception of adolescents in a Brazilian metropolis. Journal of Injury and Violence Research 12: 153-69.

Taquette, Stella, and Denise Monteiro. 2019. Causes and consequences of adolescent dating violence: A systematic review. Journal of Injury and Violence Research 11: 137. [PubMed]

Tussey, Brian Ermon, and Kimberly Tyler. 2019. Toward a comprehensive model of physical dating violence perpetration and victimization. Violence and Victims 34: 661-77. [CrossRef]

Urbizagastegui, Rubén. 2011. La colaboración de los autores en la literatura producida sobre la Ley de Lotka. Ciência da Informação 40: 266-79.

WHO. 2017. La violencia infligida por la pareja y la salud de la mujer. Available online: https://www.who.int/gender/violence/who_ multicountry_study/summary_report/chapter4/es/(accessed on 1 November 2021).

Wincentak, Katherine, Jennifer Connolly, and Noel Card. 2017. Teen dating violence: A meta-analytic review of prevalence rates. Psychology of Violence 7: 224-41. [CrossRef]

Wu, Yanqi, Jie Chen, Hui Fang, and Yuehua Wan. 2020. Intimate partner violence: A bibliometric review of literature. International Journal of Environmental Research and Public Health 17: 5607. [CrossRef] [PubMed] 
Yanez-Peñúñuri, Libia Yanelli, Jorge Arturo Martínez-Gómez, and Cesar Armando Rey-Anacona. 2019. Therapeutic intervention for victims and perpetrators of dating violence: A systematic review. Revista Iberoamericana de Psicologia y Salud. 10: 107-21.

Zych, Izabela, Carmen Viejo, Elena Vila, and David P. Farrington. 2019. School bullying and dating violence in adolescents: A systematic review and meta-analysis. Trauma, Violence, $\mathcal{E}$ Abuse 2: 397-412. 